\title{
唐みファンの性能と内部流れに関する研究*
}

\author{
河 瀬 宗 之*1, 福 富 純一郎*2 \\ 中 瀬 敬 之年, 桑 内 忠 昭*3
}

\section{A Study on Characteristic and Internal Flow Condition in a Winnowing Fan}

\author{
Muneyuki KAWASE, Junichiro FUKUTOMI,
} Yoshiyuki NAKASE and Tadaaki KUWAUCHI

\begin{abstract}
This paper describes the performance in the winnowing fan, which are used for head feeding type combines mainly used in Asia. The effects of blade angle and the bracket configurations at the inlet on the efficiency and internal flow conditions are experimentally investigated. The fan efficiency and the uniformity of flow along an axis are improved by reforming blade angle and bracket shape with holes. In addition, in this experiment we found that both of these two methods uniform the velocity distributions at fan exit and combination of these two methods make it possible to improve the fan efficiency in the limited design condition.
\end{abstract}

Key Words: Velocity Distribution, Internal Flow, Turbomachinery, Fluid Machinery, Winnowing Fan

\section{1. 緒言}

コンバイン等に用いられている脱穀機は, 稲・麦の 稈からもみ(実)の部分を分離する装置と，この分離過 程で生ずるもみやわらくず等が一体となった状態か ら，もみの部分のみを選別する装置から構成されてい る.

後者を実現するための装置は，選別室を形成して， 底がスりット状になったチャフシーブやストローラッ ク等から構成されるシーブケースを摇動することによ って，もみとわらくず等を般送・分離しながら，その 下方にラジアルファンを設けて，その風力を利用して 選別を行うものである.このシーブケースを除いた選 別装置一式，あるいは，ラジアルファン部分近傍を一 般に唐み(1)(2) というが, 以下本論文中では, ラジアル ファンのことを唐みファン(3)または, 単にファンと記 †.

一方，他の産業で実用化されている一般的なラジア ルファンは羽根枚数 6〜8 枚, ファン効率 $50 \sim 60 \%$ (才

*原稿受付 1998 年 6 月 26 日.

*1 正員, 徳島大学大学院 (臣 770-0814 徳島市南常三島町 2-1).

*2 玵員, 徳島大学工学部.

*3 徳島大学工学部.

E-mail : m-kawase@kubota.co.jp
ープン形)である(4). しかし，市販されているコンバ イン用のほとんどの唐みファンは安価にするために羽 根枚数を 4 枚とし，しかも，作物を選別するという役 割からファンの外径に対して, ファンの軸方向の幅を 2 倍以上とる必要があるので, 横長のファンとなる(図 1,4 , および表 1 参照).

したがって, 選別性能に直接かかわる吐出し口の速 度分布の均一化が難しくなると同時氾(3)(5) (9), ファン 効率は理想的な状態でも $40 \%$ 程度(3)(5)(7)(8) が限界とな っている.

こうした背景から, 唐みファンに関して,いくつか の興味深い報告がある.例えばファン回転数が $600 \sim 800 \mathrm{rpm} の$ 範囲に扔いて, 風速分布は比較的安 定であるが，それ以上では不安定となること淐．しか も，吐出しロにおける長手方向の風速分布は山又は, W 形分布となること吕(9).さらに, 凸形の風速分布 を示す唐みファンの報告もある(9).

また，羽根を前方に傾斜したほうが風速は速くなり， 風速分布も同等か改善される傾向にあるが, 動力が増 大してしまうという問題があるということ(6) (8)など が明らかにされている。

このように,いくつかの相反する現象が発生するの で,これらを総合的に判断して，実際の製品化設計に 
おいてコンパクト化・低コスト化に挑戦寸るために は，必要な情報が必ずしも十分でないのが現状であ る。

また、コンバイン用の唐みファンは少しずっ故良を 加えられてきたが，飛躍的な選別能力を高めるための 方策がとられていないのが現状である。したがって， 大幅なファン効率の向士と，速度分布の均一性の向上 を図って，さらに，現状より高回転域で運転すること を可能とした唐みファンを実現しながら，コンパクト 化を強力に推進するための研究が必要となっている。

そこで，本論文は，以上のことをいまえて，ファン 效率を高めながら，しかも，高国転域での速度分布を 可能な限り均一化するための因子を見つけ出すことを 目指して詳細な笑験を行った。

\section{2. 実験装置および実験方法}

本研究に用いた唐みファンは現在二条刈りコンバイ ンに使用されているものを用いた。唐みファンとケー シングの概略寸法等を表 1 と図 1 に示す.

羽根車は，図 3 に示すような軸方向に二次元のもの を用いた。この羽根本浪回転方间をプラスとして，7 種類の傾斜角度 $\alpha(-70,-60,-50,-35,-25,-9.4$, $0^{\circ}$ ) の羽根を樹脂 (ABS) で作成し，‥部裏这して使う

Table 1 Specification of winnowing fans

\begin{tabular}{|c|c|c|}
\hline & Number & 4 \\
\hline$\nabla$ & Inside diameter & 141. \\
\hline$\pi$ & Outside diameter & 281 \\
\hline - & Breadth & 460 \\
\hline \multirow[t]{2}{*}{ 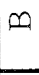 } & Angle of inclination & $-50 \sim 59.8$ \\
\hline & Rotational speed ;N(r.p.m.) & 1500 \\
\hline & Diameter of suction port; $\mathrm{D}(\mathrm{mm})$ & $\phi 230, \square 210$ \\
\hline$\infty$ & Width of delivery port; $\mathrm{L}(\mathrm{mm})$ & 510 \\
\hline $\bar{c}$ & Height of delivery port $; \mathrm{H}(\mathrm{mm})$ & 104 \\
\hline 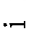 & Area of suction port ; $A_{1}\left(\mathrm{~mm}^{2}\right)$ & 85533.5 \\
\hline$\sim$ & Area of delivery port; $\mathrm{A}_{2}\left(\mathrm{~mm}^{2}\right)$ & 53183.7 \\
\hline$\pi$ & $\mathrm{L} / \mathrm{D}$ ratio & $2.16 \sim 2.22$ \\
\hline & $\mathrm{A}_{1} / \mathrm{A}_{2}$ ratio & \\
\hline
\end{tabular}

Winnowing fan impel ler

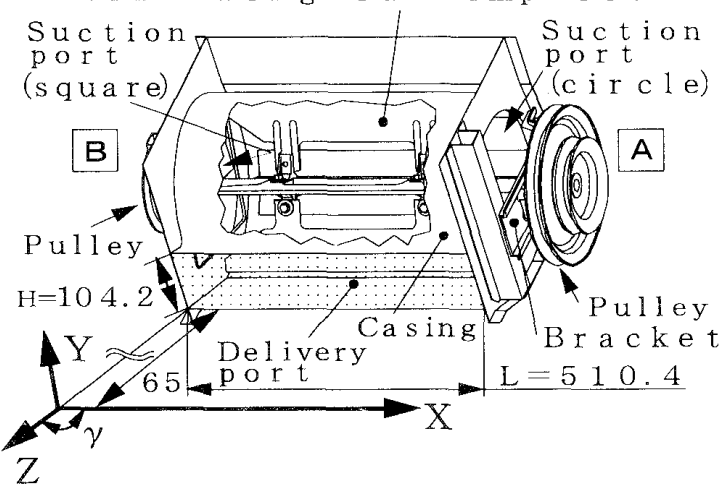

Fig. I Schematic illustration of winnowing fan
ことにより命計 11 種類のファンの性能試験を行った。 このため板曆と取付ボスの関係により，表と裏の取付 差は，単純に士0符号の差とはならなかった。例え 汱，一5 $0^{\circ}$ 傾斜した壮根を逆に取付けると $43.4^{\circ}$ 傾斜し た州根車となった(四 $3 ， 4$ 参照)。

また，吸大り逝くにあるファンの回転軸の取付用ブ ラケット(忷1，8参照）は従来形状と，それに穴を2筒 所設けた形状とした。

実験装置の製作ならびに性能試験はJISB 8330 に 規定されている送風機試験力法に基づいて行った。

その概略について述べる。应 1 に执いて，A部を上 方，B部炎下方にセットした後，図 2 に示すようにフ ァンの駆動は，軸の下方(B 部)に実機と闰じプーリを

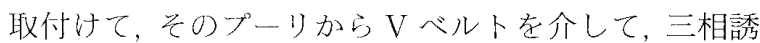

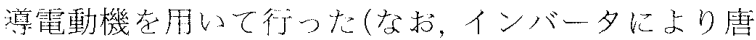
タファンの山転数を変化させることを可能にしてい る)。

な扔，以下の実験では，A部のプーリは外して，フ

Winnowing fan

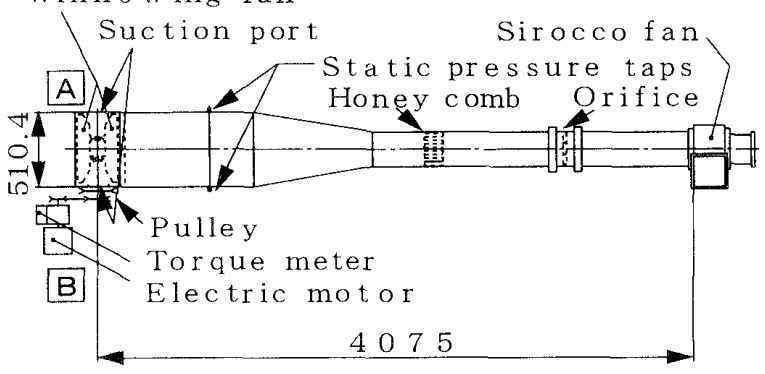

Fig. 2 Experimental apparatus

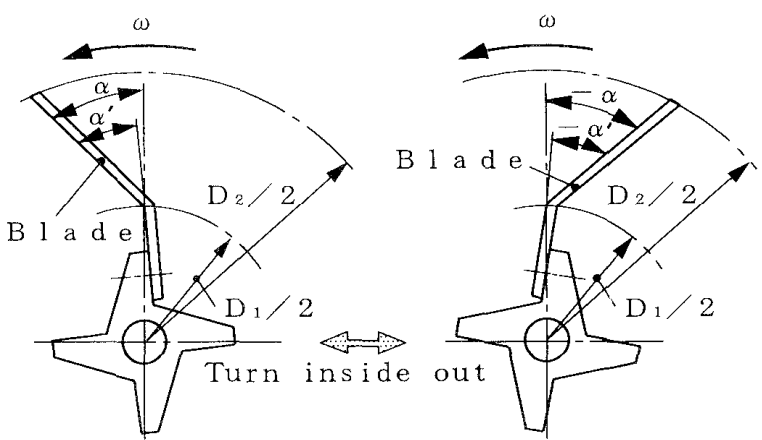

Fig. 3 The simplified model of an angled winnowing fan impeller

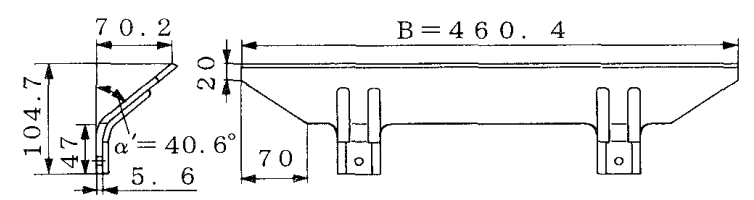

Fig. 4 Shape and dimension of fan blade $\left(\alpha=43.4^{\circ}\right.$ and $\left.-50^{\circ}\right)$ 
アンの回転数は $1500 \mathrm{rpm}$ を標準状態として試験を行 つた(従来品より $250 \mathrm{rpm}$ 回転数を高めて運転してい る).

装置の構成は唐みファンの回転により, 両側の吸入 口(図 1,2 参照) から空気を吸い込み, 約 $4 \mathrm{~m}$ の測定 管路を通り，補助送風機を介して大気中に放出する構 造とした。測定管には静圧測定孔(ファン中心より $920 \mathrm{~mm}$ の位置に設置)，整流格子(ファン中心より $2200 \mathrm{~mm}$ の位置に先端部を設置)，流量測定用のオリ フィス(ファン中心より $3032.5 \mathrm{~mm}$ の位置に設置)を 設けた。回転数 $N$ は，三相誘導電動機の軸端に取付 けた電磁ピックアップにより, 駆動トルクTはトー ションバー形式のトルク検出機によって行った.

なお，実験デー夕の整理は下式に基づいて行った。

圧力係数 $\phi=2 P_{t} /\left(\rho U_{2}^{2}\right)$

流量 係数 $\phi=Q /\left(\pi D_{2} B U_{2}\right)$

動力係数 $\lambda=2 L /\left(\rho \pi D_{2} B U_{2}^{3}\right)$

ファン効率 $\eta=Q P_{t} /(\omega T)=\psi \phi / \lambda$

ここで, $P_{t}$ がファン出口の全圧, $U_{2}$ は羽根車の外 周速度であり $U_{2}=\pi D_{2} N / 60, Q$ は流量, $L$ は軸動力, $T$ は軸トルク, $\rho$ は空気密度, $\omega$ は回転角速度を表 す.

吐出し部の流動状態の測定には, 直径 $4.8 \mathrm{~mm}$ の三 孔ピト一管を用いた(ファン中心より $285 \mathrm{~mm}$ の位置 で测定). 静圧屿図 2 に示す吐出し管に設けた静圧孔 で測定し，一方，動压は測定された流量と静圧測定装 置の管路断面積から算出した平均流速加ら求め，これ らの静圧と動压の和からファン全圧を求めた。

\section{3. 実験結果および考察}

$3 \cdot 1$ 羽根の傾斜角度の影響＼cjkstart唐みファンの取付 角度 $\alpha$ を前向き，抒よび，後向きに変化させた場合の 性能特性をそれぞれ図 5,6 に示す。

図 5，6の中で，まず，压力係数・動力係数に着目す ると，羽根の傾斜角度 $\alpha$ が増大した場合，動力係数の 上昇が比較的少ない中で, 压力係数の増加割合が大き くなる傾向が明りょうに現れた。

またここの傾向は前向きファンになるほどより明確 になるが，前傾角が $59.8^{\circ}$ まで大きくなると，压力係 数が上昇する反面, 動力係数が大きく増大するので問 題であると考えられる。

なお，圧力係数が增大する理由として，羽根の取付 角度 $\alpha$ が大きくなるにつれて, 羽根出口角 $\beta_{2}$ が大き くなり, 羽根車出口の絶対速度が增大して, 全压へッ ドが上昇したため高圧力が得られたと考えることがで きる。

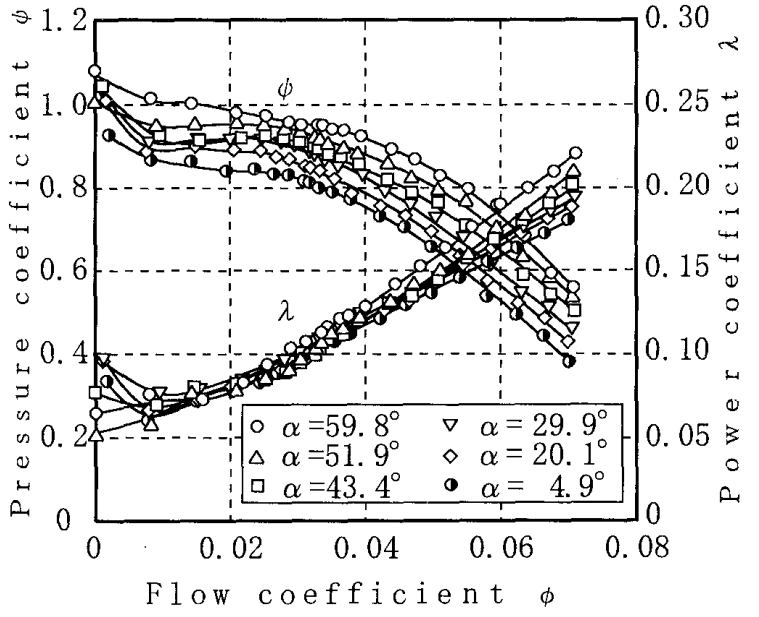

(a) Power and pressure coefficient

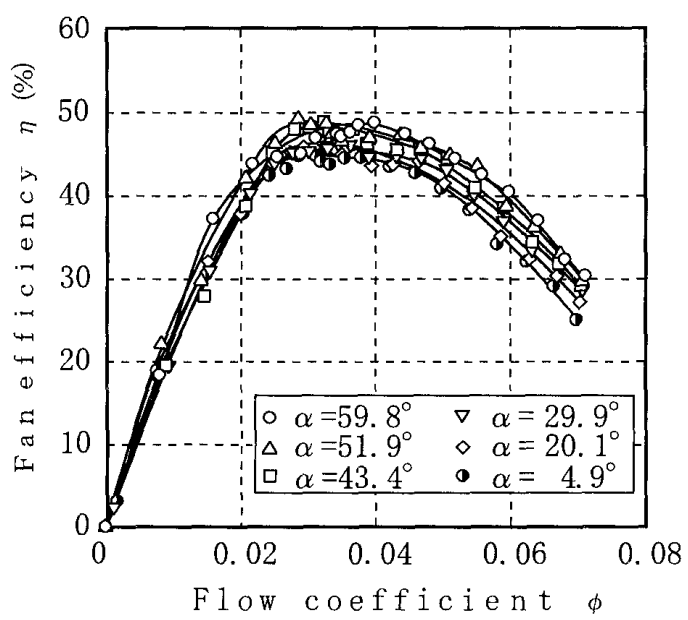

(b) Fan efficency

Fig. 5 Characteristic curves of winnowing fans $\left(\alpha=4.9 \sim 59.8^{\circ}\right)$

例えば，傾斜角度 $\alpha$ が $4.9^{\circ}$ ，羽根出口角 $\beta_{2}$ が $92.45^{\circ}$ (以下，これを標準の角度として，この角度を有 するファンを標準ファンと記すことにする)と, 羽根 の傾斜角度 $\alpha$ が $51.9^{\circ}$, 出口角が $113.43^{\circ}$ の場合の羽 根車の出口部の速度の三角形について考える。 その仮 定として, Wiesnerの滑り係数(10) が唐みファンにも 適応できるものとして, 設計点 (流量係数 $\phi=0.07$ )の 速度の三角形を計算すると, 絶対速度 $V_{2}$ が $12.77 \mathrm{~m} /$ $\mathrm{s}$ から $14.13 \mathrm{~m} / \mathrm{s}$ に増加し， $10.6 \%$ の速度上昇が予測 できる(図 7 参照)。

したがって, 羽根出口角 $\beta_{2}$ の増大による絶対速度 の増大が本実験結果 (厈力係数の増大)の要因の一つで あると考えることができる。

次に，ファン効率に着目すれば，前述の圧力係数と 動力係数の関係に対応して, 羽根が前傾するほど最高 効率が上昇することがわかった。 


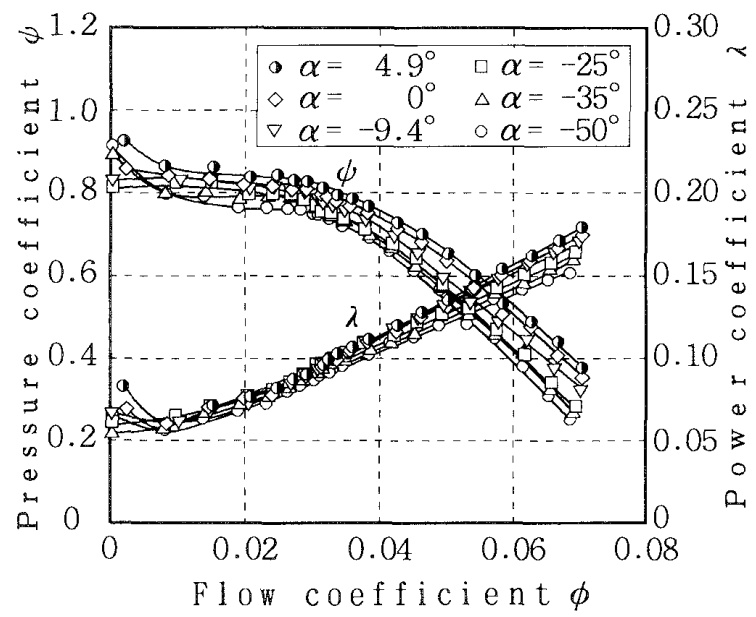

(a) Power and pressure coefficient

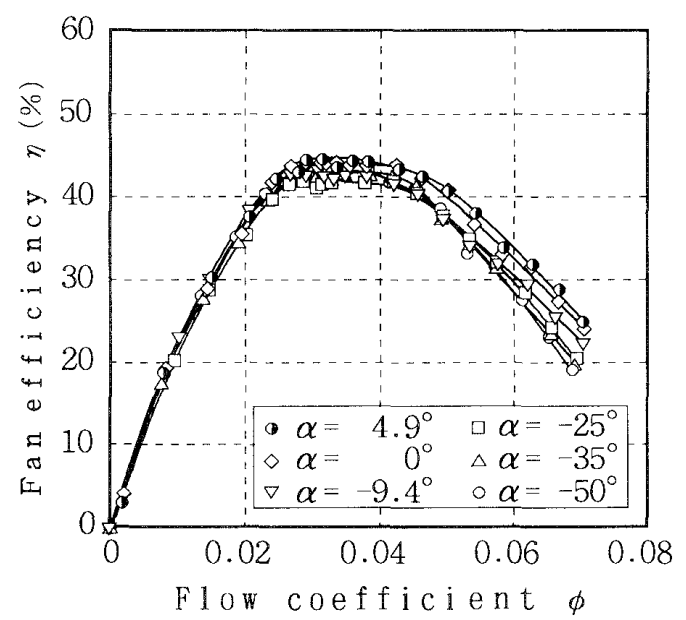

(b) Fan efficency

Fig. 6 Characteristic curves of winnowing fans $\left(\alpha=-50 \sim 4.9^{\circ}\right)$

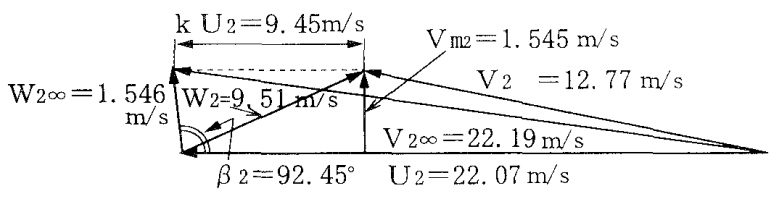

(a) $\quad \alpha=4.9$

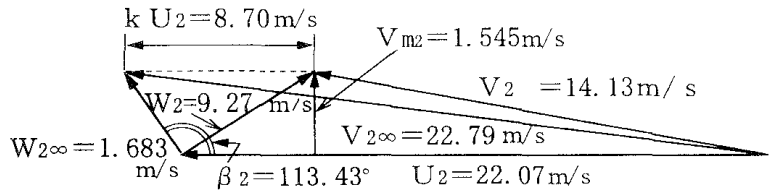

(b) $\alpha=51.9$

Fig. 7 Velocity triangles at impeller exit $\left(\alpha=4.9^{\circ}\right.$ and $\left.51.9^{\circ}\right)$

例えば，羽根傾斜角度が標準の場合と $51.9^{\circ}$ の場合 を比較すると, ファン効率が設計点(流量係数 $\phi=$ 0.07 )で $25.1 \%$ から $29.9 \%$ になり，最高効率点では 44.8\%から $49.4 \%$ になっ。このように, 羽根走前向

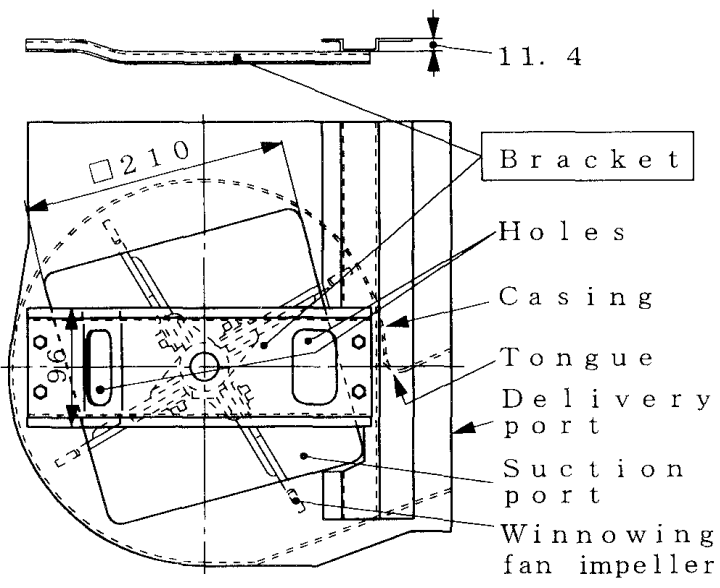

Fig. 8 Schematic illustration of the bracket

きにして, 羽根出口解 $\beta_{2}$ を大きくすることの有効性 が明確になった。しかしながら，前述のように，堕力 係数と動力係数の関係加ら，羽根の前傾角を $59.8^{\circ}$ ま で傾斜させると動力係数が著しく増大することから， ファン效率の向、上はほとんどなくなる。したがって， このファンにおいては，動力係数をあまり上昇させず に，压力係数を大きく、昇させることが可能となる羽 根の前傾角 $43.4 \sim 51.9^{\circ}$, 羽根出口角 $110.3 \sim 113.4^{\circ}$ が有効な羽根車の傾斜角度と考えられる。

$3 \cdot 2$ 唐みファンの吸気ロの影響＼cjkstart唐みファンを 設計するうえで吸気口( $\mathrm{A}$ 部が円形, B 部が方形)に は，ファンの同転軸を因定するためのブラケットの取 付けが必要となる(B 部の例を図 8 に示す)。このブラ ケットと收入几のすきまは $\mathrm{A}, \mathrm{B}$ 部で各々 $40 \mathrm{~mm}$, $11.4 \mathrm{~mm}$ しかないので，ブラケットが空気吸入時の 抵抗になると考え、ブラケットに二つの穴を設けた ( $\mathrm{A}$ 部で $3638 \mathrm{~mm}^{2}, \mathrm{~B}$ 部で $3253 \mathrm{~mm}^{2}$ ).

その結果を怄 9 に示寸。网 9 中, 黒塗りの記号は穴 なし，白报さの記号は公ありの場合をそれぞれ表す。 闵 9 に扔いて標準ファンのブラケット穴の有無に着目 すると，ブラケット穴により，高い压力係数が得られ ると同時に，高流量域で，その影響がさらに顕著とな つている。しかも，穴の有無による動力係数の変化は 高流量域に瑟るまで棌とんど発生していない。こ机に 伴って、ファン効辫が大幅に上昇していることがわか った。

例えば，標準羽根のブラケット穴の有無の差につい て検討を加えてみると，ファン効率が最高効率点で 44.8\%から $46.3 \%$ に昇した。このことから, ブラケ ット穴を設けることによって，空気吸入時の損失の一 部を改曐できることがわかった。

同様に51.9`傾斜させたファンにおいて，その取付 


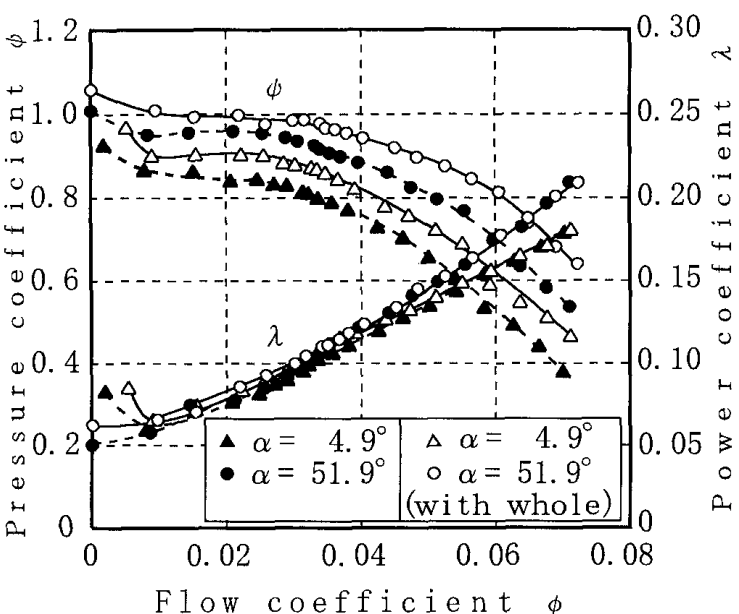

(a) Power and pressure coefficient



(b) Fan efficency

Fig. 9 Characteristic curves of winnowing fans (Effect of the bracket cofiguration)

用ブラケットに穴をあけた場合, 前傾効果と穴の効果 の相乗効果が確認できた．例えば，標準羽根車のブラ ケット穴なしの場合と, $51.9^{\circ}$ 羽根車の羽根を傾斜さ せて，しかも，ブラケット穴を設けた場合の比較をす ると, ファン効率が最高効率点に招いて, $44.8 \%$ か $50.7 \%$ に昇した。また，兩者とも最高効率点よりも 高流量域で, ファン効率の向上が極めて顕著となり, これらの改良がファン性能を向上するために有効な因 子であることがわかった。

一方，このファンの実用性を考えた場合，ファン効 率の向上江加えて, 均一な風速を均一な方向に吐出す ことが重要な設計要件となる。そこで, 以下, これら の点について, 検討を加えることにする。

$3 \cdot 3$ 唐みファン吐出し口の速度分布 まず, 吐 出し口に扔ける速度分布に関する実験結果を(詳細な 条件は後述する), 幅方向デー夕と高さ方向を同時に 示したものが図 14 である(なお, 図 14 において, $X-$

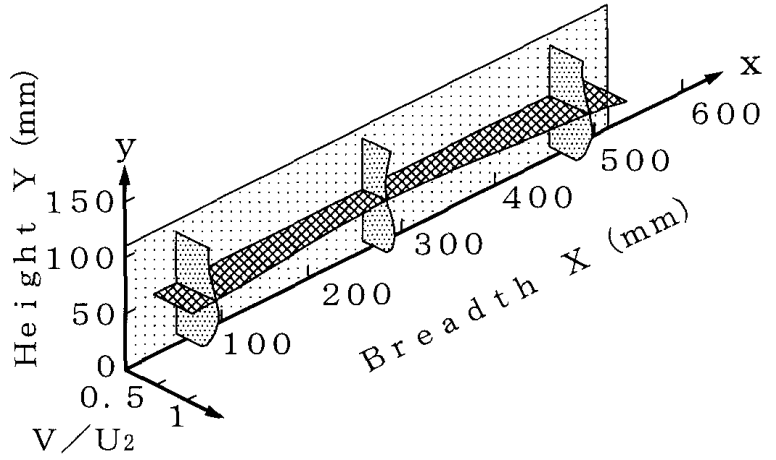

(a) $\alpha=4.9^{\circ}$



(b) $\alpha=43.4^{\circ}$

Fig. 14 Schematic illustration of velocity distributions at the delivery port $\left(\alpha=4.9,43.4^{\circ}\right)$

$Z$ 平面内の速度を $V$ と定義している)。

図 14 より，ファンの傾斜角度を $43.4^{\circ}$ にすれ壮，極 端に横方向に長い(約 4.9 倍) 唐みファンにおいて, 比 較的安定した均一な流れがより広い領域で実現できる ことが明らかになった. 以下，この点を中心に詳しい 説明を加元る。

$3 \cdot 3 \cdot 1$ 吐出し口の軸方向の速度分布 流量係数 $\phi=0.07$ の場合のファンの吐出し口近傍 $(Z=65 \mathrm{~mm}$ の位置)の速度分布を測定した。 その結果を図 10 に 示す. 図 10 はファン昍出し口の長手方向を $X$, 高さ 方向を $Y$ として $Y=55 \mathrm{~mm}$ の位置を固定して長手 方向の速度分布を測定した。なお, 測定点 $X$ は両端

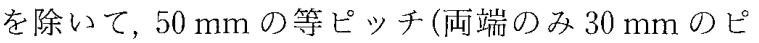
ッチ)でずらしながら, 合計 11 点の速度を測定した ( $X, Y, Z$ の座標系は図 1 参照).

羽根の傾斜角度 $\alpha$ は標準の角度と $43.4^{\circ}$ の 2 種類で 行ったまず，前者の場合，凹形の速度分布となった。 すなわち，横長のファンなので，吸込口から吸入した 空気が，中央部まで十分に流れ込む前に吐出し口へ向 かう流れになったと予測される。な扔，これらの結果 は従来の報告とほぼ同様の傾向を示守(3)(5) (9).

一方, 後者の場合, 凹形の速度分布における底の位 


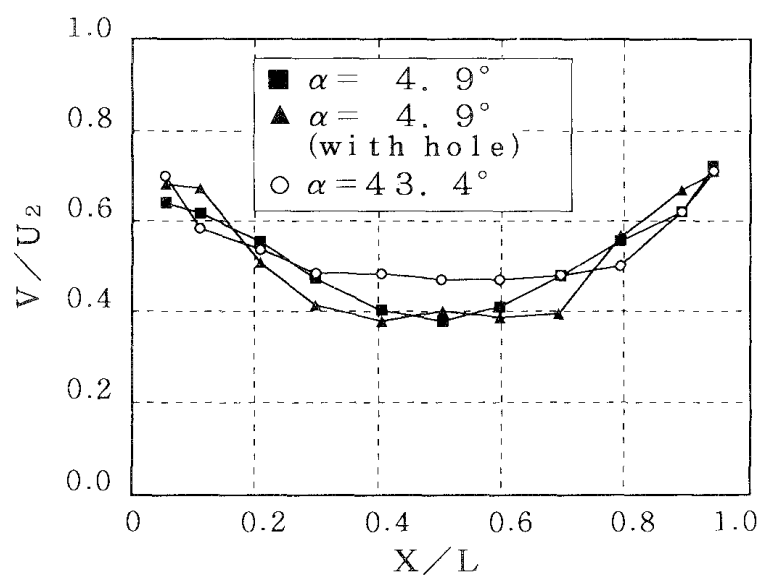

Fig. 10 Velocity distributions in breadth direction at the delivery port

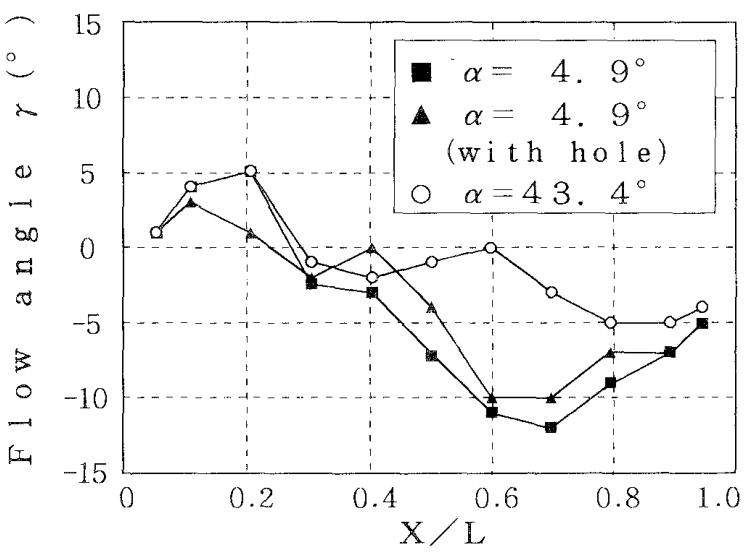

Fig. 11 Distributions of flow angle in breadth direction at the delivery port

置 (速度の比率 $V / U_{2}$ で無次元化している)が前者に比 ベ約 $9 \%$ 上昇した。さらに，中央部で山形々なってい た速度分布が大幅に改善さ扎て, 测定面の横幅 $L て ゙$ $X$ 無次元化した位置の值姑 $0.3 \sim 0.80$ 範囲にわた って平たんとなり, 幅方向に対して速度の均一化が促 進さ机たことがわかる。

以上のことより，空気が中央部まで流れ込む割合が 増大したと推祭することができる。

问椂に，ブラケットに穴を設けた実験を標準羽根車 で行った。その結果, 中央部での速度分布の旧形が平 たんとなり，X/Lの值で $0.3 \sim 0.7$ 範囲にわたって 均一化の傾向が認められた。しかし，43.4\%傾斜した 羽根車の上うに，四形の分布の底を上昇拝るには至ら ず，均一化が図れる領域も少なくなっていることがわ 加た。

さて，今まで叶出し口の速度の大きさについて検討 を加えてきたが，次に，その方向に対寸る検討を行う。 まず, ファンの出口の流机の角度 $\gamma(X-Z$ 平面内

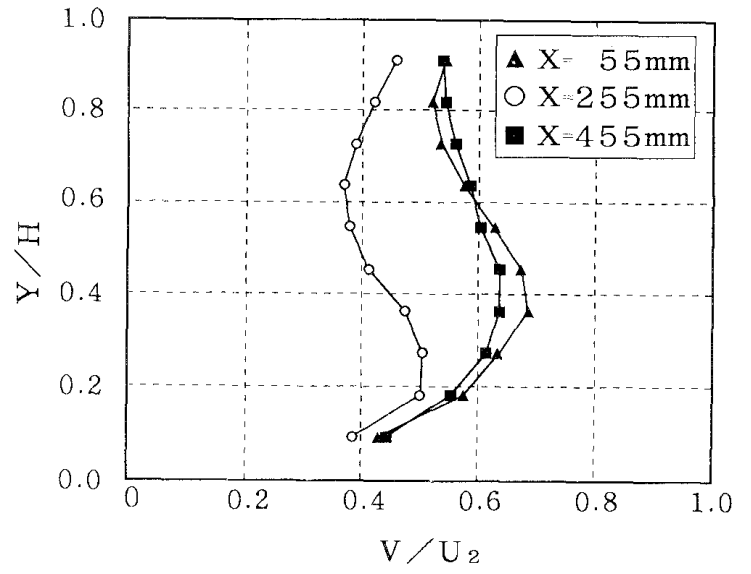

Fig. 12 Velocity distributions in height direction at the delivery port $\left(\alpha=4.9^{\circ}\right)$

の $Y$ 軸回りの傾斜角度とし，十の場合は $X$ が大き い側へ向かう流れとなる。図1)を測定した結果を目 11 宗主。

この実験結果は, 標準羽根車の場合, $\mathrm{A}$ 部 $(X / L=$ 1）から横幅の30\%程度中に入ったところにおいて, 流れの今向が最大 $-12^{\circ}$ 傾斜し, B 部 $(X / L=0)$ から 横幅の $20 \%$ 程度入ったところで最大 5 傾斜した流れ となった。またてれらの值は中に入るにしたがって， 开いに近づく傾向に西るが，中央部において $7^{\circ}$ の傾 斜的度があった。

このように，流れが傾斜する割合はA 部近傍でよ り強く出る。これは，上方 (A 部)にはプーリがないの で，より多くの空気がそこから入り，それが均一に中 央まで送ら扎ないためにこの現象が発生したと考える ことができる。

一方, $43.4^{\circ}$ 傾斜した羽根車の流れの方向は全領域 にわたって \pm 50 の範囲に人り安定した流れとなった。 しかも，中央部付近は 0 - $2^{\circ}$ の傾斜を示し，前述のよ うなプーリの影響はほとんどなくほほ活均一な安定し た流れが形成されていることが確認できた。

さらに標準羽根車を用いて，取付用のブラケット部 の穴の有無に関して同様の垁験を行った。その結果， 穴をあけることにより，角度の変化が若干少なくなっ たが，顕著な差は諗められず，流れの方向を安定化す る役割としては，ブラケット穴はほとんど貢献してい ないことがわかった。

$3 \cdot 3 \cdot 2$ 吐出し口の高さ方向の速度分布 最後に, 高さ方向の速度分布の测定を行った。その方法は $Z$ $=65 \mathrm{~mm}$ の位置を測定面 $(X-Y$ 平面)として, 長手 方向の距離 $X$ が $55,255,455 \mathrm{~mm}$ の 3 種類の位置に 着目して, 高さ力向の位置 $Y$ を等間隔に $10 \mathrm{~mm}$ のピ 


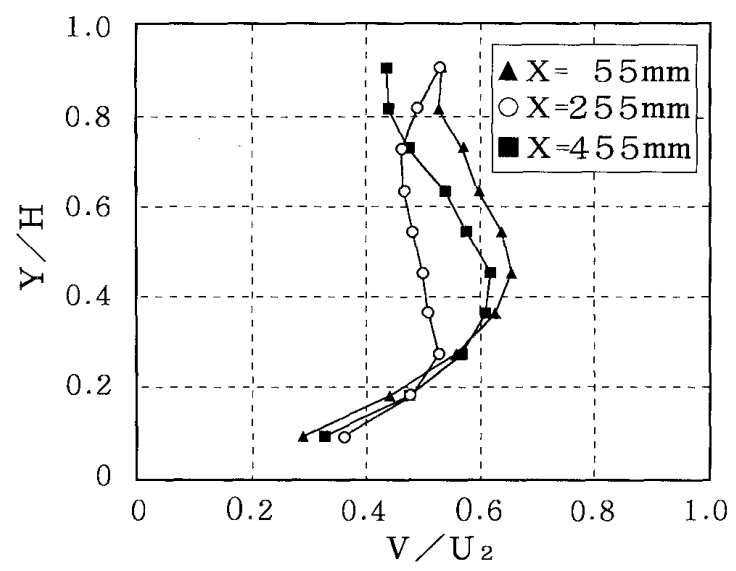

Fig. 13 Velocity distributions in height direction at the delivery port $\left(\alpha=43.4^{\circ}\right)$

ッチでずらしながら，各々10点の測定を行った。

その結果を図 12,13 に示す。まず，図 12 に示す標 準羽根車において，X=55 mmと $455 \mathrm{~mm}$ の挙動に 着目すると，高さが中央部よりやや下方で速度のピー クを示し，両端では速度が下がる傾问となった。また， 中央部 $(X=255 \mathrm{~mm})$ に打ける高さ方向の速度変化は $30 \%$ 高さで速度の速い領域，60\%の高さで, 速度の 遅い領域が発生して，凹凹の激しい分布となった。し 加も，全体の速度の分布も著しく低下 $(X=55 \mathrm{~mm}$ の 位置の速度と比較して平均 $25.5 \%$ 低下) した。次 に, 図 13 に示すように, 羽根の傾斜角度 $\alpha$ が $43.4^{\circ}$ の ファンの場合, 空気吸入部近傍 $(\mathrm{A}, \mathrm{B}$ 部)では同様な 傾向を示すが, 壁近傍の高さの低いところで,やや速 度の低い領域が生じ問題である。この点については別 途適切な機会に報告をする予定である.

一方, 長手方向に対し中央部 $(X=255 \mathrm{~mm})$ の位置 での速度分布は，標準ファンのような極端な山凹のあ る速度分布が大幅に緩和され，高さの中央部付近でほ ぼ均一な流水となった。しかも, 速度は $X=55 \mathrm{~mm}$ の位置での速度に詨して，平均 $11.4 \%$ の低下にとどま る効果があった。

次に, 図 15 はファンの傾斜角度が標準の場合と, $43.4^{\circ}$ 傾斜した場合の出口の流れの角度 $\gamma(X-Z$ 平面 内の $Y$ 軸回りの傾斜角度) を測定した結果を示す.

図 15 より, 標準羽根車は中央部近傍 $(X=255 \mathrm{~mm})$ において，一7〜-8 の傾斜があるのに対して，43.4 前傾させた羽根車は同じ位置で, 0 - $1^{\circ}$ の傾斜とな り, 安定した速度の方向となった。

しかしながら，高さの上・下限付近では流れ角の方 向がばらついていることがわかり，これらは今後の課 題である.

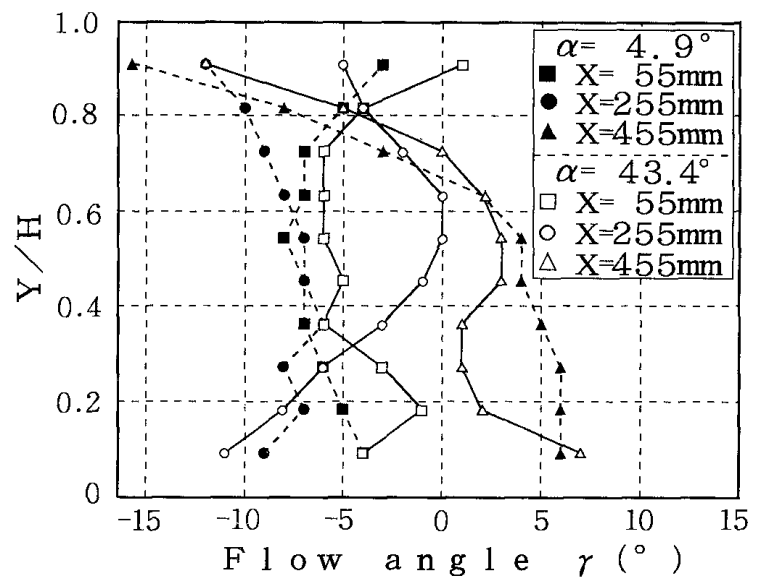

Fig. 15 Distributions of flow angle in height direction at the delivery port $\left(\alpha=4.9,43.4^{\circ}\right)$

このように一部課題を残すものの，多くの領域にわ たって, $43.4^{\circ}$ 前傾させたファンは, 標準ファンより 流れの傾斜角度が小さくなっており，速度の方向の面 からも安定していることがわかった。

以上の実験結果から，羽根を前傾した羽根車を使用 することによって,ファン効率を高められた理由は, 絶対速度の上昇に加えて, 吐出し口近傍の速度(速度 の大きさ，および，その方向の分布)の均一化と密接な 関係にあることが明らかになると同時に，この傾斜羽 根車は, ファン効率の向上と, 速度分布の均一化を同 時に満足することが可能であり，実用上極めて有効な 方法であるという結論を導くことができた。

\section{4. 結言}

本研究に用いた唐みファンに扔いて, 羽根の傾斜角 度・羽根車の取付ブラケットが，内部流れやファン性 能に及ぼす影響を実験的に検討した結果，以下のこと が明らかとなった。

（1）羽根の傾斜角度を前傾にすることにより, 動 力係数の上昇を最小限に抑えながら, 圧力係数を上昇 させることによって，ファン効率を高めることができ る.

（2）吸入部の損失は，羽根車取付用ブラケットに 設けた究により改善することができる。

（3）前傾角をもつ羽根車とブラケットの穴を組合 せることによって，ファン効率向上に対して，相乗効 果が発生する。

（4）標準の羽根(直線羽根) は吐出しロで, ファン の軸方向(長手方向)に詨して，凹形の速度分布を示す が, 前傾した羽根 $\left(\alpha=43.5^{\circ}\right)$ ではこれが改善され，速 度の一様化が促進される傾向が認められた。さらに， 
流れ角 $\gamma$ の変化も前傾した羽根のほうが小さく，流れ がより吐出し口に向かっている。

（5）ファン出口中央部 $(X=255 \mathrm{~mm})$ で，高さ方 向 $(Y$ 方向)の速度分布について検討した結果, 前傾 した羽根 $\left(\alpha=43.5^{\circ}\right)$ は標準の羽根と比較して, 一様な 速度分布を示すと闰時に，吐出し方向 $(Z$ 方向) からの 流れ角のずれも小さいことがわかった。しかし，阔端 部 $(X=55,255 \mathrm{~mm})$ では問題が残り，これらは今後 の課題である。

最後に，実験および，データ整理に関してご協力い たたいた徳島大学大学院工学研究科学生の山川佳宏 君, 徳鼻大学工学部学生の岸森慎一郎君, 平田大至君 に謝意を表す。

\section{文献}

（1）薗柇光雄・活加6 名, 新版農業機械学，(1980），199201，
朝㝓書占.

（2）石原帠・注か 7 名, 新農業機械学，(1987)，201-203, 朝倉 静店

（3）農業機械学会編，改言農機械ハンドブック，(1977)，650, コ叮社.

（4）日本機械学会編, 機械工学便覧 B 5 流体機械, (1991)，B 5140, 好善.

（5）杉本正雄, 海筫0)研究第 1 報, 農機誌，10 3(1948)，75-84。

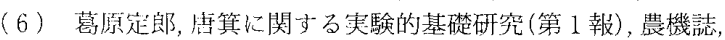
16-3・4 (1955), 143-146.

（7）常松栄・南部悟，唐箕に関する研究 (第 2 報)，坓機敦，19 $1(1957), 28-32$

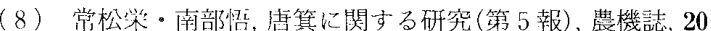
1(1958), 41-44.

（9）小川海寿・狩野秀男・松田良一，やさしい譨作業0実際 シリーズ 5 (第 5 巻)频物調整の機械化，(1960)，47, 新農林 社.

(10) Wiesner, F. J., A Review of Slip Factors for Centrifugal Impellers, Trans. ASME, J. Eng. Power, 89$4(1967), 558-572$ 